\title{
Determining forest litter interception in an area of the Cerrado sensu stricto
}

\section{Determinação da interceptação pela serrapilheira em área de Cerrado sensu stricto}

\author{
Lívia Malacarne Pinheiro Rosalem ${ }^{1}$, Jamil Alexandre Ayach Anache ${ }^{1}$ and Edson Wendland ${ }^{1}$ \\ ${ }^{1}$ Escola de Engenharia de São Carlos, Universidade de São Paulo, São Carlos, SP, Brasil \\ E-mails: liviarosalem@gmail.com (LMPR), jamil.anache@usp.br (JAAA), ew@sc.usp.br (EW)
}

Received: September 07, 2017 - Revised: March 13, 2018 - Accepted: April 18, 2018

\begin{abstract}
Mainly due to the difficulty of directly measuring forest litter interception, many empirical studies on water balance in forests have disregarded this component. In order to assess the magnitude of forest litter interception in an area of the Cerrado s.s., an estimate of the intercepted volume was made based on equations from two forest litter parameters (Cmax and Cmin) obtained from laboratory assays and monitoring the forest litter quantity. The estimates obtained from the litter interception for 2015 and 2016 were compared with the calculated values of evapotranspiration and internal precipitation of the study area. The total volume of litter interception corresponded on average to $13.4 \%$ of the internal precipitation and $8.5 \%$ of the total rainfall. Regarding the total annual evapotranspiration, the evaporation from the forest litter interception volume corresponded on average to $10.3 \%$ (122 mm) of this total. Forest litter interception for areas such as the Cerrado sensu stricto can have a significant impact on the water balance. This shows the need for directly measuring the forest litter interception, providing more accurate determinations of the rainfall partitioning in these forest areas.
\end{abstract}

Keywords: Litter interception device; Storage capacity; Evapotranspiration.

\section{RESUMO}

Devido principalmente à dificuldade em medir diretamente a interceptação pela serrapilheira, muitos trabalhos empíricos sobre balanço hídrico em florestas têm desconsiderado essa componente. A fim de avaliar a magnitude da interceptação pela serrapilheira em uma área de Cerrado sensu stricto, foi realizada uma estimativa do volume interceptado a partir de equações de dois parâmetros da serrapilheira (Cmax e Cmin), obtidas a partir de ensaios em laboratório, e do monitoramento da quantidade de serrapilheira. As estimativas obtidas de interceptação pela serrapilheira para os anos de 2015 e 2016 foram comparadas com os valores calculados de evapotranspiração e de precipitação interna da área de estudo. O volume total interceptado pela serrapilheira correspondeu em média a 13,4\% da precipitação interna e 8,5\% da precipitação total. Em relação à evapotranspiração total anual, a evaporação do volume interceptado pela serrapilheira correspondeu em média a 10,3\% (122 mm) desse total. A interceptação da serrapilheira para áreas como as de Cerrado sensu stricto pode ter impacto significativo no balanço hídrico. Isso evidencia a necessidade de medições diretas da interceptação pela serrapilheira, possibilitando determinações mais precisas da partição da precipitação nessas áreas florestais.

Palavras-chave: Dispositivo de medição da interceptação pela serrapilheira; Capacidade de armazenamento; Evapotranspiração. 


\section{INTRODUCTION}

The Cerrado is the second largest biome in South America and has a direct influence on 8 out of the 12 largest hydrographic regions in Brazil, contributing to the formation of important basins such as those of the São Francisco, Tocantins-Araguaia, Paranaíba, Paraná and Paraguay rivers (OLIVEIRA et al., 2015). However, although the Cerrado is an important regulator of mass and energy exchanges with the atmosphere (MIRANDA et al., 1997), there is little research on the hydrological processes of the Cerrado (MARKEWITZ et al., 2006).

Distribution analysis, or partitioning, of gross rainfall is very important for water resources management in hydrographic basins with forested areas. Concerning these areas, it is imperative to understand how the forest influences the interception process and the distribution of rainfall in this environment (GIGLIO; KOBIYAMA, 2013).

In studies on the interception process in forests, usually the forest litter interception has been neglected, which is mainly due to difficulties of carrying out direct field measurements (APARECIDO et al., 2011; GERRITS et al., 2010). Thus, interception measures, when performed, usually focus only on the canopy and stem interception (LIMA; NICOLIELO, 1983; HONDA, 2013; TONELLO et al., 2014; OLIVEIRA et al., 2014; JUNQUEIRA JÚNIOR, 2016; THOMAZ; ANTONELI, 2015; SARI; PAIVA; PAIVA, 2015; 2016).

Litter is the layer formed above the soil by leaves and woody material vegetation, resulting from the balance of senescence and decomposition processes (DODONOV et al., 2016). It influences and regulates functional processes that occur in an ecosystem, and is able to control various physical, chemical and biological properties in the soil. Thus, it is characterized as a key factor in maintaining forest systems and controlling of erosion processes, also acting as a rainfall interception mechanism (CAMPOS et al., 2008). In their paper on the Cerrado sensu stricto, Oliveira et al. (2016) state that changes in the forest litter and vegetation composition throughout the year tend to promote different responses in the interception and roughness processes of the soil surface, facilitating water retention.

Some studies show that the forest litter interception can be significant, up to $20 \%$ of the gross rainfall (TSIKO et al., 2012). However, despite its importance, little research in the field of hydrology has assessed its role on hydrological processes (BULCOCK; JEWIT'T, 2012).

Considering the possible impact of forest litter interception on the water balance, the aim of this study was to estimate this interception in an area of the Cerrado sensu stricto (Cerrado s.s.) (also known as wooded Cerrado) based on information on physical litter parameters. Therefore, results to determine the storage capacity of the forest litter obtained in the laboratory, using meteorological monitoring data and the amount of forest litter from this area of Cerrado s.s. were used.

\section{MATERIAL AND METHODS}

Since 2012, studies have been carried out in a 300 ha area of the Cerrado s.s., located in the municipality of Itirapina, São Paulo state, Brazil (Figure 1). The plant density is estimated at 15,522 individuals per hectare and the tree height generally ranges between 6 and 7 meters (REYS et al., 2013).

According to the Köppen classification, it has a humid subtropical climate with hot summers and dry winters (Cwa) (ALVARES et al., 2014). The average annual rainfall for the

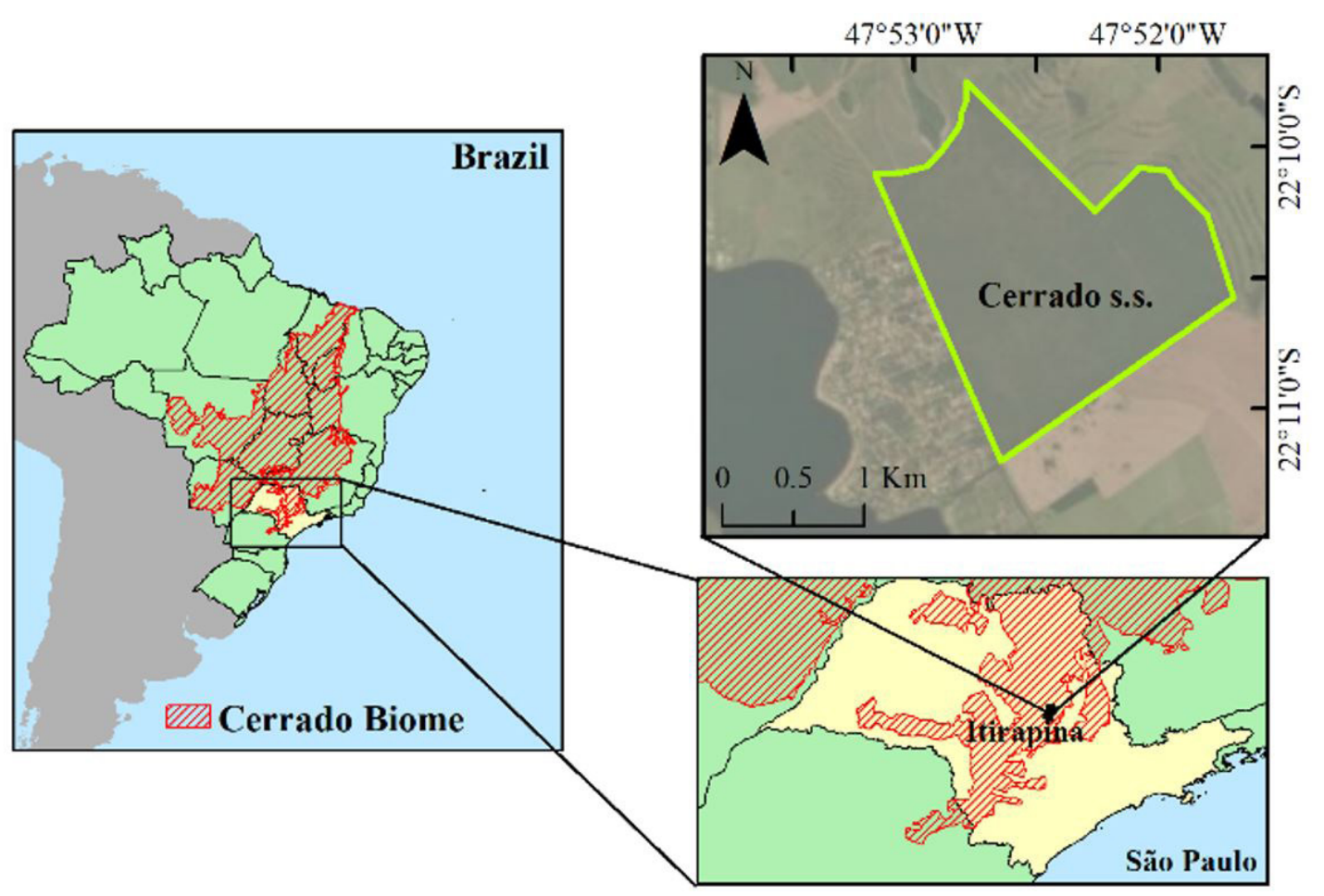

Figure 1. Location of the study area of the Cerrado sensu stricto in the municipality of Itirapina, São Paulo state. 
region is $1496 \mathrm{~mm}$, based on data from 1973 to 2014 obtained from the weather station at the Centre for Water Resources and Environmental Studies (CRHEA in Portuguese) at the University of São Paulo. The rainy season begins in September and the highest rainfall is from December to February (CABRERA et al., 2016).

From March, 2015 to February, 2016, forest litter was collected from this area of the Cerrado s.s. to verify the variation in the amount of dry mass. Therefore, three monthly litter samples were collected manually from areas of $0.25 \mathrm{~m}^{2}(50 \mathrm{~cm} \times 50 \mathrm{~cm})$ in random places in the study area, at least 10 meters distant from each other, making a total of 36 samples. The collected samples were taken to the laboratory and oven dried for 24 hours at $100^{\circ} \mathrm{C}$ to determine the dry weight (Figure 2).

To determine the maximum and minimum capacities of water storage (Cmax and Cmin, respectively) of the forest litter from the Cerrado s.s., assays were carried out in the laboratory. Cmax represents the maximum volume that the forest litter retains during a rainfall event and this value is obtained when the rain stops. The Cmin value is found after the rainfall event when all the drainable water (or gravity water) is drained out of the forest litter. This value is important because it is the volume of water intercepted in the litter, which will only get out of forest litter by evaporation (PUTUHENA; CORDERY, 1996; HELVEY, 1964; SATO et al., 2004; LI; NIU; XIE, 2013).

Assays were carried out in the Hydraulic Laboratory at the São Carlos School of Engineering at the University of São Paulo. The Litter Interception Device (LID) was used on these assays, which is a device specially developed for forest litter interception measurements (Nº of deposit in INPI: BR 102017 010107-0) (ROSALEM, 2017). Different forest litter samples of 3 mass quantities were used in LID, which were determined based on the quantities observed in the area of Cerrado s.s.. Concerning the monitoring results, the following values were adopted: maximum $\left(2.94 \mathrm{~kg} \cdot \mathrm{m}^{-2}\right)$, mean $\left(1.44 \mathrm{~kg} \cdot \mathrm{m}^{-2}\right)$ and minimum $\left(0.62 \mathrm{~kg} \cdot \mathrm{m}^{-2}\right)$, considering the accommodation area of the samples in the LID $\left(0.16 \mathrm{~m}^{2}\right)$.

In the assays, the forest litter samples deposited in the LID were submitted to different intensities of simulated rainfall events. The rainfall intensities used were determined from an Intensity-Duration-Frequency (IDF) curve for the study area, obtained from a series of maximum daily rainfall data over 40 years. The data used to construct the curve were obtained from the conventional CRHEA weather station, approximately $4 \mathrm{~km}$ from the area of the Cerrado s.s. under study. Considering the equation of the determined IDF curve (Equation 1) 3 different intensities to simulated rainfall events were calculated, considering rainfall durations of 60 minutes (LI; NIU; XIE, 2013) and return periods of 2, 20 and 100 years.

$$
I=\frac{1249 \cdot T R^{0.15}}{(t+11.39)^{0.81}}
$$

Where: $\mathrm{I}$ is the rainfall intensity $\left(\mathrm{mm} \mathrm{h}^{-1}\right)$, TR is the return period (years) and $t$ is the rainfall duration ( $\mathrm{min}$ ).

The return periods of 2, 20 and 100 years were adopted because they had recurrent rainfall intensities ( 2 years), low recurrent
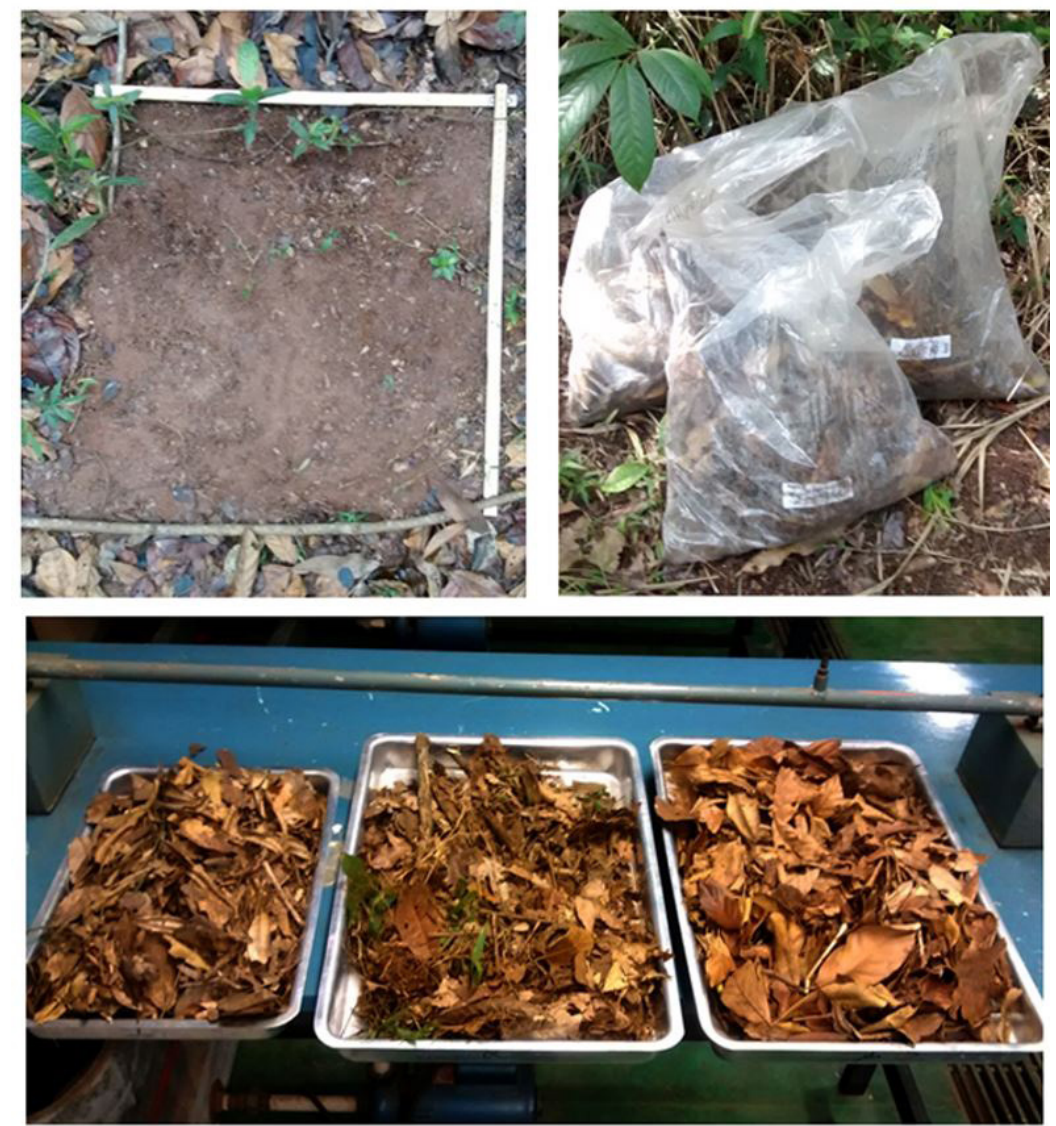

Figure 2. Litter collection in the study area and samples after being oven dried. 
(20 years) and extreme (100 years). In addition, as sprinkler nozzles that allow greater accuracy in the simulated rainfall event were not used in the rainfall simulator, we chose to adopt these return periods to ensure that the simulated rainfall error was lower than the difference between the intensities. Assays were carried out with water under ambient pressure in the rainfall simulator on the LID, supplied by a reservoir connected to a pump, which was connected to a frequency inverter by which output flow was controlled.

The choice of return periods also considered whether the intensities and the duration of simulated rainfall, which would be obtained from using this return period, would be similar or close to those proposed by other authors (SATO et al., 2004; GUEVARA-ESCOBAR et al., 2007; LI et al., 2013). Thus, in the assays carried out in the laboratory, the intensities of 40, 60 and $75 \mathrm{~mm} \mathrm{~h}^{-1}$ were adopted with an observed simulated rainfall mean error of $3.2 \mathrm{~mm} \cdot \mathrm{h}^{-1}$.

However, during the initial assays, it was observed that in order for the samples to remain homogeneously humid, the rainfalls used should be longer. Thus, it was accepted, following the initial assays, that for simulated intensities, rainfall events lasting $180 \mathrm{~min}$ would be suffice to moisten the entire sample. Therefore, in the final analyses, rainfalls lasting 180 mins and intensities of 40, 60 and $75 \mathrm{~mm} \mathrm{~h}^{-1}$ were considered. The intensities originally calculated for the duration of $60 \mathrm{~min}$ were maintained as the new intensities, estimated for a duration of 180 minutes, would be very similar to each other.

The Cmax and Cmin parameters were determined for each of the three mass quantities analyzed $\left(2.94,1.44\right.$ and $\left.0.62 \mathrm{~kg} \cdot \mathrm{m}^{-2}\right)$, under each of the adopted rainfall intensities $\left(40,60\right.$ and $\left.75 \mathrm{~mm} \mathrm{~h}^{-1}\right)$, considering in each case three replicates of the assay; totaling 27 assays lasting $180 \mathrm{~min}$ each. Based on these laboratory results, the $C$ max and $C$ min values were obtained for each assay. Considering the Cmax and Cmin results, the linear relationships between the amount of dry forest litter mass and the mean Cmax and $C$ min values were determined. More information about the assays carried out can be found in Rosalem (2017).

Considering the results of the litter monitoring in the Cerrado area and using the equations obtained (Equations 3 and 4), the Cmax and Cmin values for the observed months were determined. To complete the 2015 and 2016 series, the average amounts of forest litter were repeated in the corresponding months in which there were no monitoring data. In order to verify if the samples collected in a given month were different from each other (which could lead to more uncertainties in the extrapolation of the series for the months in which there was no monitoring) or if the amount of forest litter was significantly different between the months, the Tukey test with $99 \%$ significance was used.

After obtaining the Cmax and Cmin values for each one of the months, the volume intercepted by the forest litter was estimated based on the internal precipitation data. The internal precipitation was monitored from August to December 2015 using seven tipping bucket rain gauges below the vegetation canopy. The gross precipitation $(\mathrm{P})$ was monitored at a weather station, about $1 \mathrm{~km}$ from the study area.

Based on the gross precipitation data, monitored between 2015 and 2016, the daily internal precipitation was estimated, considering the total percentage value of the internal precipitation monitored from August to December, 2015. To construct the internal precipitation series (IPs), only the daily gross rainfall events more than $2 \mathrm{~mm}$ were considered as a rainfall volume less than this value is more likely to be totally intercepted by the forest canopy (ROWE, 1983; SCHELLEKENS et al., 1999; REID; LEWIS, 2009). Having determined the internal precipitation series, the maximum dynamic (Cmax values) and static (Cmin values) interceptions were estimated for the daily events.

As the Cmin value represents the volume stored in the forest litter which, at any given time, can return to the atmosphere through the evaporation process, the daily evapotranspiration (ET) in the Cerrado area was compared with Cmin estimated values. The daily evapotranspiration $\left(\mathrm{mm}^{\mathrm{d}} \mathrm{d}^{-1}\right.$ ) was calculated for 2015 and 2016 using a technique based on simplified energy balance (PRIESTLEY; TAYLOR, 1972) (Equation 2). Therefore, soil heat flux, net radiation, temperature and relative humidity data were used, which were collected in the study area every $10 \mathrm{~min}$. The Priestley and Taylor coefficient ( $\alpha$ ) for the Cerrado s.s. (0.96) was obtained from the research carried out by Cabral et al. (2015).

$$
E T=\alpha(1 / \lambda)[(s(R n-G)) /(s+\gamma)]
$$

Where: $\mathrm{G}$ is the soil heat flux (MJ.m- $\left.{ }^{2} \cdot \mathrm{d}^{-}{ }^{1}\right), \mathrm{Rn}$ is the net radiation $\left(\mathrm{MJ} \cdot \mathrm{m}^{-}{ }^{2} \cdot \mathrm{d}^{-1}\right), \lambda$ is the latent heat of vaporization, $\mathrm{s}$ is the slope vapor pressure curve $\left(\mathrm{kPa}^{\circ} \mathrm{C}^{-1}\right)$ and $\gamma$ is the psychrometric constant.

\section{RESULTS AND DISCUSSION}

The Cmax and Cmin values were obtained from the laboratory assays carried out. The linear relationship between the dry litter mass and the Cmax and Cmin mean values is presented in Equation $3\left(\mathrm{R}^{2}=0.90\right)$ and $4\left(\mathrm{R}^{2}=0.96\right)$

$C \max =0.6771 x+0.851$

Cmin $=0.5384 x+0.5638$

Where $x$ represents the amount of forest litter $\left(\mathrm{kg} \cdot \mathrm{m}^{-2}\right)$.

By applying the results from monitoring the amount of forest litter in the Cerrado to these equations, the highest values calculated for the Cmax and Cmin parameters were observed for August, in which a greater amount of forest litter was found (Table 1). This result was expected as the two parameters are closely related with the mass amount of forest litter.

The results of the Tukey test $(p \geq 0.01)$ confirmed that there is no significant differences between the samples collected in the same month, or among months) (Table 1). Thus, the results indicate that the spatial heterogeneity of the Cerrado s.s. did not cause significant differences between the samples collected in the same month. Furthermore, the differences observed among the monthly results of monitoring the amount of forest litter are not statistically significant. Therefore, although there was a greater amount of forest litter in August, this is not statistically significant.

The maximum and minimum storage capacity estimated, represented by the Cmax and Cmin values, varied between 1.46 and $2.51 \mathrm{~mm}$, and between 1.05 and $1.88 \mathrm{~mm}$, respectively. These values resemble those found by other authors of $1.8 \mathrm{~mm}$ (GERRITS; PFISTER; SAVENIJE, 2010) and $1.51 \mathrm{~mm}$ (MARIN et al., 2000) for Cmin, and 1.02 to $1.97 \mathrm{~mm}$ (DUNKERLEY, 2015) and $1.1 \mathrm{~mm}$ (STEIDLE NETO et al., 2012) for Cmax. Although the 
studies were carried out with forest litter in different forests, it can be observed that the estimated storage capacities in this research presented values of the same order of magnitude.

Based on the internal precipitation (IP) monitoring, carried out from August to December, 2015 in the study area, it was observed that $65.5 \%$ of $\mathrm{P}$ (where $\mathrm{P}=376 \mathrm{~mm}$ ) crossed the canopy as IP. During this period, the highest and the lowest accumulated daily average values were $55 \mathrm{~mm} . \mathrm{d}^{-1}$ and $0.7 \mathrm{~mm} . \mathrm{d}^{-1}$, respectively. Considering these results, in the estimates of the volume intercepted by vegetation, an average value of IP equal to $65.5 \%$ of $\mathrm{P}$ was considered to calculate the daily internal precipitation values.

It should be mentioned that adopting a fixed IP value throughout the year causes more uncertainty regarding the results. However, in this study, it was not possible to adjust the IP data as a function of $\mathrm{P}$ due to the small amount of data. In this paper, the stemflow volume was not considered which, despite not being a significant percentage volume in relation to the total gross precipitation representing about $1 \%$ in the Cerrado s.s. (OLIVEIRA et al., 2015), may be important for obtaining more accurate evaporation values from the forest litter.

The Cmax and Cmin parameter values (Table 1) were used to estimate the maximum dynamic and static interception of forest litter for each of the rainfall events considered in the series. The estimate of the volume evaporated by forest litter (VEL) was obtained based on the Cmin values, understood as the potential maximum volume evaporated by forest litter after the rainfall event. The Cmin values were accepted as an estimate of the VEL and were compared to the internal precipitation series (IPs) (Figure 3). In the analyzed period, 2015 and 2016, the IPs were 934 and $880 \mathrm{~mm}$, respectively, and the accumulated gross precipitation of the series of events considered (Ps) was $2.791 \mathrm{~mm}$, distributed in 187 events (only those events with gross rainfall greater than $2 \mathrm{~mm}$ were considered).

In 2015 and 2016, the VEL percentage compared to the IPs was $14.2 \%(133 \mathrm{~mm})$ and $12.6 \%(111 \mathrm{~mm})$, respectively. If the total gross precipitation $(\mathrm{P})$ is considered throughout the whole study period $(2.864 \mathrm{~mm})$, the evaporation from the forest litter corresponded to $8.5 \%(244 \mathrm{~mm})$ of the total. In a forest of Fagus sylvatica forest in Luxembourg, Gerrits et al. (2010) found that $22 \%$ of the internal precipitation evaporated from the forest litter. Tsiko et al. (2012) observed that $20 \%$ of the net rainfall was retained from Msasa leaf litter (brachystegia spiciformis) in Zimbabwe; and Bulcock and Jewitt (2012), also based on field measurements, found interception values for three different types of forest litter between 6 and $12 \%$ of the total rainfall. Therefore, the estimated VEL presented values of the same order of magnitude as some direct measurements.

Comparing the monthly VEL and IPs accumulations (Figure 4), there was a marked increase in VEL up to IPs values close to $170 \mathrm{~mm}$. In months where the IPs were above this value, the VEL did not increase significantly. It can be observed that when the IPs almost doubled from $169 \mathrm{~mm}$ to $321 \mathrm{~mm}$ (increase of $89 \%$ ), the increase in the monthly VEL was only $2.45 \mathrm{~mm}$, which corresponds to about $11 \%$ of the maximum VEL.

Table 1. Result of monitoring the amount of forest litter in the Cerrado s.s. area and the Cmax and Cmin values obtained by the regression curves.

\begin{tabular}{|c|c|c|c|c|c|}
\hline \multirow[t]{2}{*}{ Date } & \multicolumn{3}{|c|}{ Dry litter mass (kg.m $\left.{ }^{-2}\right)$} & \multicolumn{2}{|c|}{$\begin{array}{c}\text { Storage capacity } \\
(\mathrm{mm})\end{array}$} \\
\hline & Min* & Mean & $\operatorname{Max}^{* *}$ & $\mathrm{Cmax}$ & $\mathrm{Cmin}$ \\
\hline Mar/15 & 0.98 & $1.26 \mathrm{a}$ & 1.54 & 1.70 & 1.24 \\
\hline Apr/15 & 0.72 & $0.90 \mathrm{a}$ & 1.21 & 1.46 & 1.05 \\
\hline May/15 & 1.42 & $1.72 \mathrm{a}$ & 2.12 & 2.02 & 1.49 \\
\hline Jun/15 & 0.60 & $1.16 \mathrm{a}$ & 1.67 & 1.64 & 1.19 \\
\hline $\mathrm{Jul} / 15$ & 1.06 & $1.31 \mathrm{a}$ & 1.69 & 1.74 & 1.27 \\
\hline Aug/15 & 2.18 & $2.45 \mathrm{a}$ & 2.97 & 2.51 & 1.88 \\
\hline Sept $/ 15$ & 0.89 & $1.47 \mathrm{a}$ & 2.12 & 1.84 & 1.35 \\
\hline Oct/15 & 1.38 & $1.73 \mathrm{a}$ & 2.20 & 2.02 & 1.50 \\
\hline Nov/15 & 1.02 & $1.39 \mathrm{a}$ & 2.29 & 1.86 & 1.36 \\
\hline $\mathrm{Dec} / 15$ & 1.21 & $1.26 \mathrm{a}$ & 1.31 & 1.72 & 1.26 \\
\hline Jan/16 & 0.88 & $1.26 \mathrm{a}$ & 1.89 & 1.71 & 1.24 \\
\hline
\end{tabular}

*Minimum; **Maximum. Identical superscript letters indicate non-significant differences between the averages of the groups ( $P$ value $\geq 0.01$ ).

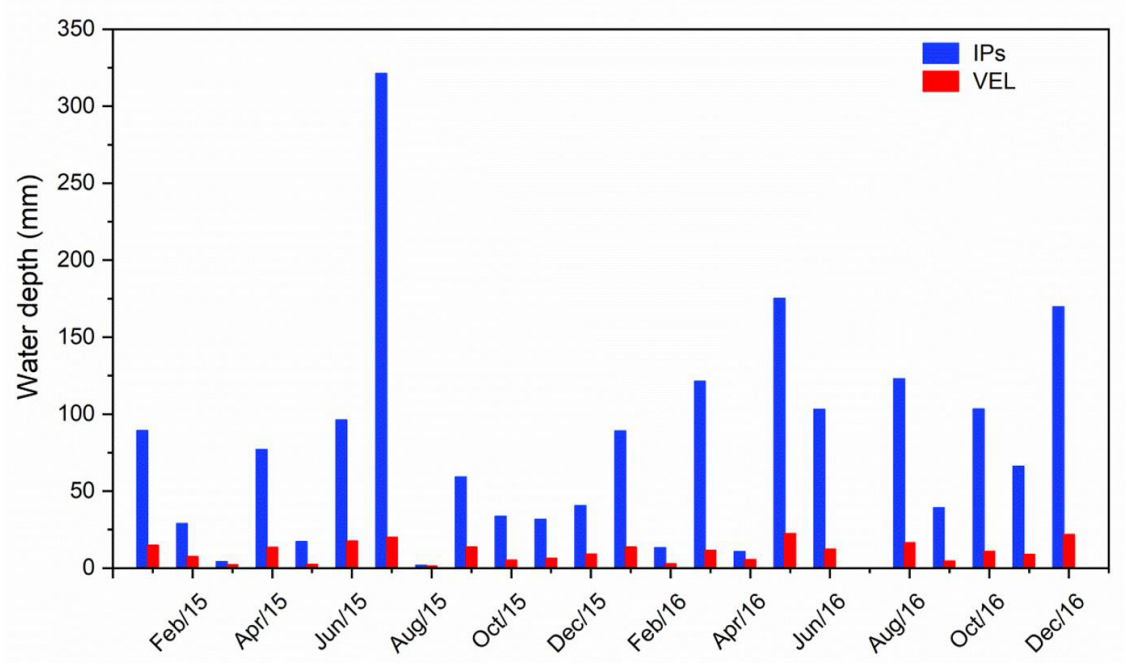

Figure 3. Monthly variation of the internal precipitation of the series of events considered (IPs) and estimated litter evaporation for a Cerrado s.s. area in 2015 and 2016. 
Regarding these two wetter months, which presented rainfall totals of $321 \mathrm{~mm}$ (Jan, 2016) and $169 \mathrm{~mm}$ (Nov, 2015), a total of 16 events took place in both of them. The volume of rainfall in the events of January, 2016 was higher than in the events of November, 2015 having possibly reached the minimum capacity (Cmin) and perhaps even exceeded the maximum storage capacity (Cmax). In the future, after installing LIDs in the Cerrado s.s. area, it will be possible to evaluate the daily variation in the forest litter storage and concomitantly the production of surface runoff in the study area by experimental plots already installed. Therefore, we will be able to observe if there is actually an increase in the surface runoff when the value of Cmax is exceeded.

As evapotranspiration is affected by the atmospheric demand, and this in turn is controlled by evaporating power of air (PEREIRA; VILLA NOVA; SEDIYAMA, 2013), daily information about evapotranspiration in the study area is directly related to the estimated daily VEL. As VEL corresponds to the intercepted volume susceptible to evaporation, daily evapotranspiration was evaluated in the Cerrado s.s. area to examine whether there was a possibility that the intercepted volume had been evaporated.

The daily evapotranspiration values (ET), calculated by the Priestley-Taylor method, were compared with the estimated VEL, and from the results it was observed that the total evapotranspiration of the daily events considered (ETs) corresponded to $571 \mathrm{~mm}$, i.e., $24 \%$ of accumulated evapotranspiration from the study period $(2.363 \mathrm{~mm})$. Considering the relationship between the monthly sums of VEL and ETs, there was an increasingly positive relationship (Figure 5), similar to the relationship between VEL and IPs.

Concerning the monthly variations of ET and ETs (Figure 6), it can be observed that they followed similar behavior to IPs (Figure 3), when the lowest values occurred at a time when there was less precipitation (April to September). The VEL presented higher values than those of ETs in May, July and August over the two years and also in September, 2015 and April, 2016.

The precipitation events were analyzed separately in order to verify the occurrence of overestimations in the series and, mainly, to detail the results in the months in which VEL values higher than those of ETs. In total, 301 rainfall events occurred, and in only 187 was the rainfall greater than $2 \mathrm{~mm}$ (IPs). Out of these 187 events, in 38 of them the estimated VEL was higher than the calculated ETs. Over $50 \%$ of these events (26 in total) occurred during the driest seasons in the region (autumn and winter), and in winter, where there is lower ET, there was a greater number of these events (18 events in total).

It should be taken into account that even on days in which the volume intercepted by the forest litter was greater than the evapotranspiration, the evaporation of this interception can still occur until the next precipitation event. Therefore, the 38 events were analyzed separately to verify if it was possible for the estimated VEL to occur the next day. Considering this more detailed analysis, it was found that among the 38 events, in only 15 of them there was rainfall on the next day. Therefore, it was less likely that the total estimated VEL occurred on those days (Table 2). The sum of VEL in these 15 days corresponded to only $8.8 \%$ of the total estimated VEL and $0.7 \%$ of gross rainfall (P), for the whole study period.

Disregarding the 15 events $(21 \mathrm{~mm})$ in which there is greater uncertainty in the estimated VEL, the corrected VEL ranges from the mean of $13.4 \%(122 \mathrm{~mm})$ to $12.2 \%(111 \mathrm{~mm})$ of the annual

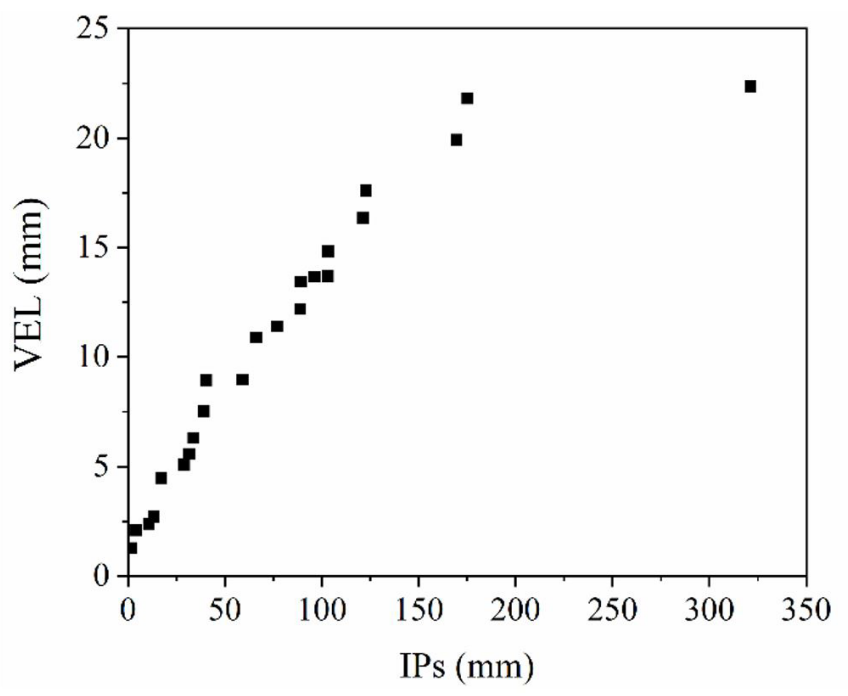

Figure 4. Relationship between the monthly accumulation of evaporation from the forest litter (VEL) and internal precipitation of the series of events considered (IPs) for a Cerrado s.s. area in 2015 and 2016.

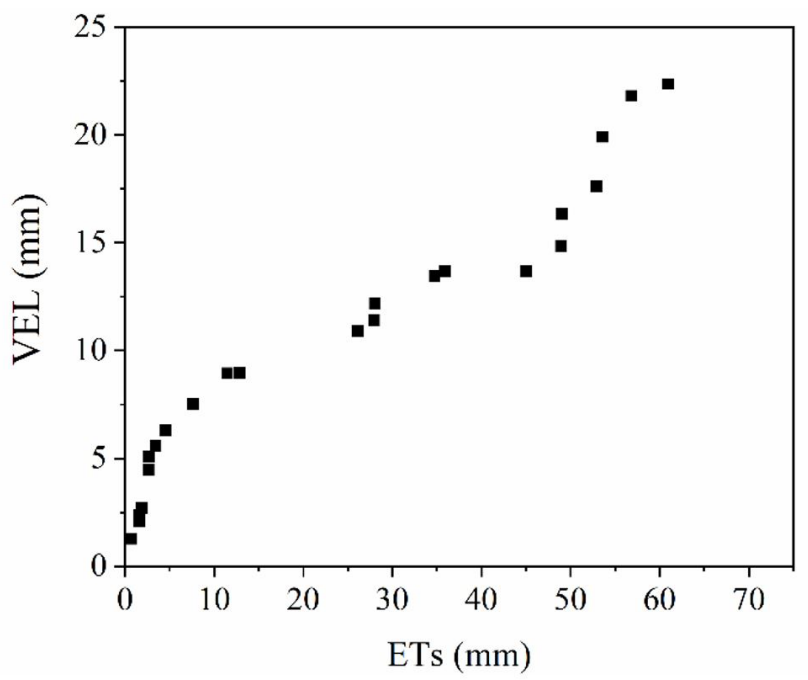

Figure 5. Relationship between the monthly accumulations of forest litter evaporation (VEL) and the total evapotranspiration of the daily events considered (ETs) for a Cerrado s.s. area in 2015 and 2016.

Table 2. Number of days in which rainfall occurred and the estimated forest litter evaporation (VEL) was greater than evapotranspiration (ET) calculated for the day. Number of days when VEL was greater than ET and that there was rainfall on the next day.

\begin{tabular}{ccc}
\hline Seasons & $\begin{array}{c}\mathbf{N}^{\mathbf{o}} \text { of days } \\
\text { VEL }>\text { ET } \\
(\mathbf{m m})\end{array}$ & $\begin{array}{c}\mathbf{N}^{\mathbf{o}} \text { of days VEL>ET and } \\
\text { rainfall on the following } \\
\text { day }(\mathbf{m m})\end{array}$ \\
\hline Winter & $18(27.6)$ & $11(16.8)$ \\
Fall & $8(10.7)$ & $2(2.1)$ \\
Spring & $6(8.4)$ & $0(0.0)$ \\
Summer & $6(7.4)$ & $2(2.5)$ \\
Total & $38(54.1)$ & $15(21.4)$ \\
\hline
\end{tabular}




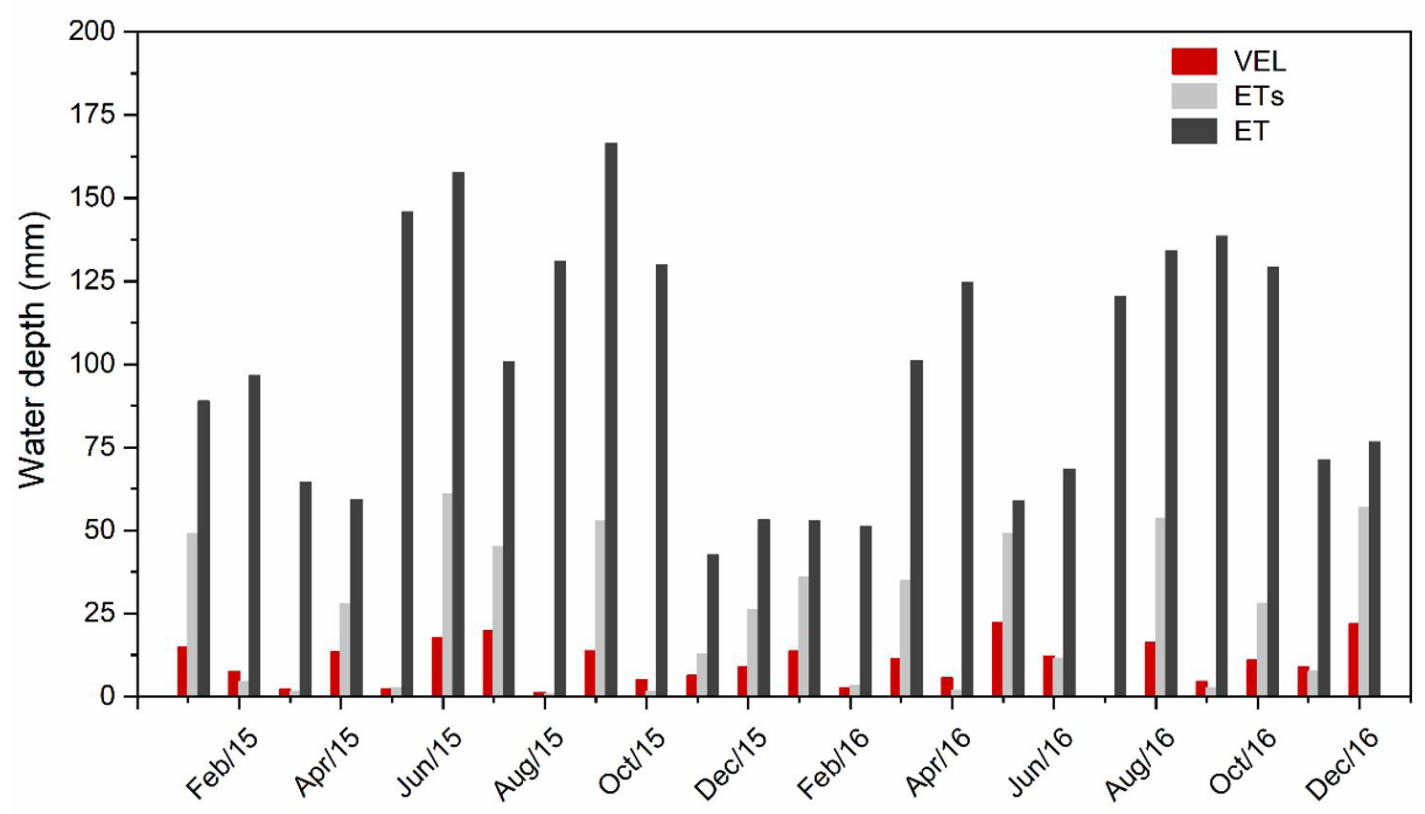

Figure 6. Monthly values of total evapotranspiration (ET), evapotranspiration in the daily events considered (ETs) and estimated forest litter evaporation (VEL) for a Cerrado s.s. area in 2015 and 2016.

IPs and from $10.3 \%$ to $9.4 \%$ of the annual ET. Analyzing the 11 events in the winter in which rainfall occurred on the following day, 9 of them occurred from 15 August to 12 September.

During the study period, August and September had a low total ET; on average only $2.9 \%$ of the annual ET. In August, there was generally a greater soil water deficit compared to the other months (ROSALEM et al., 2016), as well as lower values for relative air humidity. It is in this month that, although it is still winter in the region, the average temperature rises again (Figure 7).

The occurrence of water deficit in the soil leads to a decrease in the evapotranspiration process as water availability is one of the factors that governs the process. Cabral et al. (2015) point out, based on their results for an area of the Cerrado s.s., that the deficit of water vapor saturation increases during this drier season. In addition, despite a decrease in ET, it maintains a practically constant daily value, showing that vegetal transpiration is maintained mainly due to the deeper water reserves. Thus, due to high environmental evaporative demand, the rainfall volume at this time can be quickly evaporated.

In forests areas, the occurrence of the interception process during the driest period of the year may represent a significant difference in the amount of evapotranspiration (SEYFFARTH, 1995). Thus, due to these factors, when rainfall events occur in the dry season, the evaporation of the volume intercepted by the forest litter can be significant leading to VEL values greater than the calculated ETs.

In a study conducted in 2011 in the same area of Cerrado s.s. as this research, Alberton et al. (2014) showed that there was a period of significant seasonal flowering in the Cerrado s.s. leading to a larger number of species in the flowering period from the end of August peaking in mid September. The senescence prior to this period can be observed in the study area by the increasing amount of forest litter observed in the collection at the end of August.

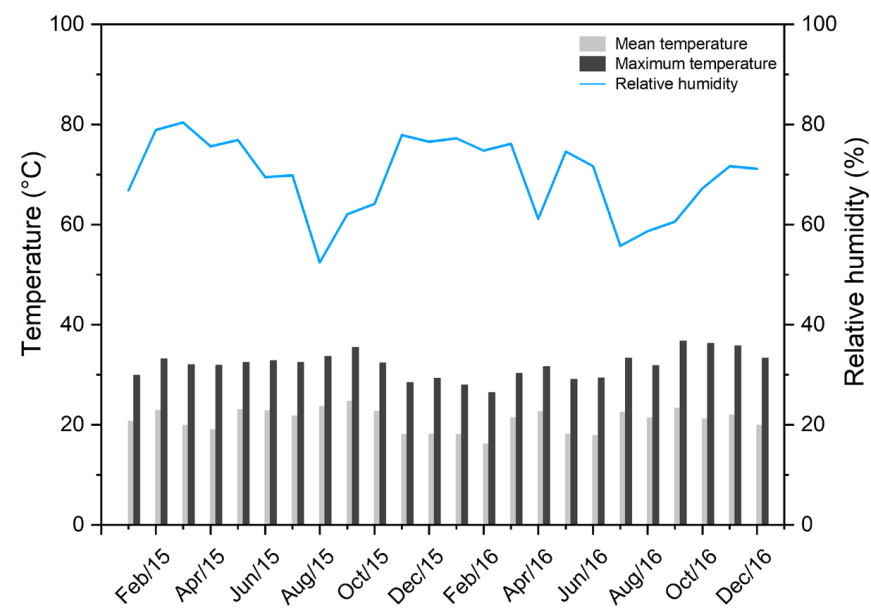

Figure 7. Mean values of the average and maximum temperatures and relative humidity, based on data observed every 10 minutes during 2015 and 2016 at a weather station $1 \mathrm{~km}$ from the Cerrado s.s. area under study.

\section{CONCLUSIONS}

Based on meteorological information and the results from the laboratory assays, the rainfall interception from the forest litter for an area of the Cerrado s.s was estimated. The results show that the maximum interception during the rainfall events reached values between 1.46 and $2.51 \mathrm{~mm}$. The minimum storage capacity $(\mathrm{Cmin})$, understood as the probable maximum evaporation from the forest litter after an event, presented values between 1.05 and $1.88 \mathrm{~mm}$.

The estimated VEL represents, on average, $8.5 \%$ of the annual gross rainfall and $13.4 \%$ of the annual IP. The comparison of daily ET with the VEL shows that, on average, VEL represents 
$10.3 \%(122 \mathrm{~mm})$ of the total annual ET. In the 187 rainfall events considered, it can be observed that 15 of them presented more uncertainty in the VEL estimation, representing $0.7 \%(22 \mathrm{~mm})$ of accumulated $\mathrm{P}$ and $8.8 \%$ of the accumulated VEL over the two years in question.

It is important to mention that magnitude of the VEL found resembles the order of magnitude pointed out in other studies. This shows that the using Cmin values for estimating VEL can be a useful tool in water balance studies.

Due to the direct relationship between the VEL estimates and the internal precipitation data, more accurate estimates can be obtained with longer internal precipitation series and by monitoring the amount of forest litter, as well as series of stemflow data.

Based on the results, the need for direct interception measurements from forest litter is clear in order to increase the accuracy of partitioning the rainfall in these forest areas. To corroborate this, estimates made in this paper will be compared in the future, using direct interception measurements from the forest litter obtained by installing LIDs in the study area.

Although the volume intercepted from the forest litter may be small in terms of isolation events, in a longer time interval the intercepted total could be significant. Thus, this intercepted volume may be relevant to the water balance, having a significant impact on the total evaporated estimates in a Cerrado s.s. area promoting further considerable reductions of water infiltration into the soil and surface runoff.

\section{ACKNOWLEDGEMENTS}

The authors thank the Fundação de Amparo à Pesquisa do Estado de São Paulo — FAPESP (grant number 2015/03806-1), and the Coordenação de Aperfeiçoamento de Pessoal de Nivel Superior CAPES (PROEX program), whose financial support made the development of the present study possible. The authors also acknowledge the Graduate Program in Hydraulics and Sanitary Engineering - PPGSHS (USP-EESC) for the scientific support, and the Arruda Botelho Institute - IAB for allowing the development of this study in the Cerrado sensu stricto vegetation.

\section{REFERENCES}

ALBERTON, B.; ALMEIDA, J.; HELM, R.; TORRES, R. S.; MENZEL, A.; MORELLATO, L. P. C. Using phenological cameras to track the green up in a cerrado savanna and its on-the-ground validation. Ecological Informatics, v. 19, p. 62-70, 2014. http://dx.doi. org/10.1016/j.ecoinf.2013.12.011.

ALVARES, C. A.; STAPE, J. L.; SENTELHAS, P. C.; GONÇALVES, J. L. M.; SPAROVEK, G. Koppen's climate classification map for Brazil. Meteorologische Zeitschrift, v. 22, n. 6, p. 711-728, 2014. https://doi.org/10.1127/0941-2948/2013/0507.

APARECIDO, L. M. T.; HONDA, E. A.; JARDIM, C. B.; SILVA, D. B. B.; DURIGAN, G. Relação entre atributos físicos de árvores do cerrado e o escoamento da chuva pelo tronco. In: CONGRESSO DE ECOLOGIA DO BRASIL, 10., 2011, São Lourenço, Anais... São Lourenço: Sociedade de Ecologia do Brasil, 2011.
BULCOCK, H. H.; JEWITT, G. P. W. Field data collection and analysis of canopy and litter interception in commercial forest plantations in the KwaZulu-Natal Midlands, South Africa. Hydrology and Earth System Sciences, v. 16, n. 10, p. 3717-3728, 2012. http:// dx.doi.org/10.5194/hess-16-3717-2012.

CABRAL, O. M. R.; ROCHA, H. R.; GASH, J. H.; FREITAS, H. C.; LIGO, M. A. V. Water and energy fluxes from a woodland savanna (cerrado) in southeast Brazil. Journal of Hydrology: Regional Studies, v. 4, p. 22-40, 2015. http://dx.doi.org/10.1016/j.ejrh.2015.04.010.

CABRERA, M. C. M.; ANACHE, J. A. A.; YOULTON, C.; WENDLAND, E. Performance of evaporation estimation methods compared with standard $20 \mathrm{~m} 2$ tank. Revista Brasileira de Engenharia Agrícola e Ambiental, v. 20, n. 10, p. 874-879, 2016. http://dx.doi. org/10.1590/1807-1929/agriambi.v20n10p874-879.

CAMPOS, E. H.; ALVES, R. R.; SERATO, D. S.; RODRIGUES, G. S.; RODRIGUES, S. C. Acúmulo de serrapilheira em fragmentos de mata mesofítica e cerrado stricto senso em Uberlândia - MG. Sociedade \& Natureza, v. 20, n. 1, p. 189-203, 2008. http://dx.doi. org/10.1590/S1982-45132008000100013.

DODONOV, P.; BRAGA, A. L.; HARPER, K. A.; MATOS, D. M. S. Edge influence on plant litter biomass i forest and savanna in the Brazilian cerrado. Austral Ecology, v. 42, p. 187-197, 2016.

DUNKERLEY, D. Percolation through leaf litter: What happens during rainfall events of varying intensity? Journal of Hydrology (Amsterdam), v. 525, p. 737-746, 2015. http://dx.doi.org/10.1016/j. jhydrol.2015.04.039.

GERRITS, A. M. J.; PFISTER, L.; SAVENIJE, H. H. G. Spatial and temporal variability of canopy and forest floor interception in a beech forest. Hydrological Processes, v. 24, n. 21, p. 3011-3025, 2010. http://dx.doi.org/10.1002/hyp.7712.

GIGLIO, J. N.; KOBIYAMA, M. Interceptação da chuva: uma revisão com ênfase no monitoramento em florestas brasileiras. Revista Brasileira de Recursos Hídricos, v. 18, n. 2, p. 297-317, 2013. http://dx.doi.org/10.21168/rbrh.v18n2.p297-317.

GUEVARA-ESCOBAR, A.; GONZALEZ-SOSA, E.; RAMOSSALINAS, M.; HERNANDEZ-DELGADO, G. D. Experimental analysis of drainage and water storage of litter layers. Hydrology and Earth System Sciences, v. 11, n. 5, p. 1703-1716, 2007. http:// dx.doi.org/10.5194/hess-11-1703-2007.

HELVEY, J. D. Rainfall interception by hardwood forest litter in the southern Appalachians. North Carolina: Asheville, 1964. (U.S. Forest Service Research Paper, 8), p. 1-8.

HONDA, E. A. Repartição da água da chuva sob o dossel e umidade do solo no gradiente fisionômico da vegetação do Cerrado. 2013. Tese (Doutorado em Ciências da Engenharia Ambiental) - Escola de Engenharia de São Carlos, Universidade de São Paulo, São Carlos, 2013. 
JUNQUEIRA JÚNIOR, J. A. Monitoramento e modelagem da interceptação da precipitação e da umidade do solo em fragmento de Mata Atlântica. 2016. Tese (Doutorado Recursos Hídricos em Sistemas Agrícolas) - Universidade Federal de Lavras, Lavras, 2016.

LI, X.; NIU, J.; XIE, B. Study on hydrological functions of litter layers in North China. PLoS One, v. 8, n. 7, p. 1-11, 2013. http:/ / dx.doi.org/10.1371/journal.pone.0070328. PMid:23936188.

LIMA, W. P.; NICOLIELO, N. Precipitação efetiva e a interceptação em florestas de Pinheiros tropicais e em uma reserva de cerradão. Revista IPEF, n. 24, p. 43-46, 1983.

MARIN, C. T.; BOUTEN, I. W.; DEKKER, S. Forest floor water dynamics and root water uptaken in four forest ecosystems in northwest Amazonia. Journal of Hydrology, v. 237, n. 3-4, p. 169183, 2000. http://dx.doi.org/10.1016/S0022-1694(00)00302-4.

MARKEWITZ, D.; RESENDE, J. C. F.; PARRON, L.; BUSTAMANTE, M.; KLINK, C. A.; FIGUEIREDO, R. O.; DAVIDSON, E. A. Dissolved rainfall inputs and streamwater outputs in an undisturbed watershed on highly wathered soils in the Brazilian cerrado. Hydrological Processes, v. 20, n. 12, p. 26152639, 2006. http://dx.doi.org/10.1002/hyp.6219.

MIRANDA, A. C.; MIRANDA, H. S.; LLOYD, J.; GRACE, J.; FRANCEY, R. J.; MCINTYRE, J. A.; MEIR, P.; RIGGAN, P.; LOCKWOOD, R.; BRASS, J. Fluxes of carbon, water and energy over Brazilian cerrado: an analysis using eddy covariance and stable isotopes. Plant, Cell \& Environment, v. 20, n. 3, p. 315-328, 1997. http://dx.doi.org/10.1046/j.1365-3040.1997.d01-80.x.

OLIVEIRA, P. T. S.; NEARING, M. A.; HAWKINS, R. H.; STONE, J. J.; RODRIGUES, D. B. B.; PANACHUKI, E.; WENDLAND, E. Curve number estimation from Brazilian Cerrado rainfall and runoff data. Journal of Soil and Water Conservation, v. 71, n. 5, p. 420-429, 2016. http://dx.doi.org/10.2489/jswc.71.5.420.

OLIVEIRA, P. T. S.; NEARING, M. A.; MORAN, M. S.; GOODRICH, D. C.; WENDLAND, E.; GUPTA, H. V. Trends in water balance components across the Brazilian Cerrado. Water Resources Research, v. 50, n. 9, p. 7100-7114, 2014. http://dx.doi. org/10.1002/2013WR015202.

OLIVEIRA, P. T. S.; WENDLAND, E.; NEARING, M. A.; SCOT'T, R. L.; ROSOLEM, R.; DA ROCHA, H. R. The water balance components of undisturbed tropical woodlands in the Brazilian cerrado. Hydrology and Earth System Sciences, v. 19, n. 6, p. 2899-2910, 2015. http://dx.doi.org/10.5194/hess-19-2899-2015.

PEREIRA, A. R.; VILLA NOVA, N. A.; SEDIYAMA, G. C. Evapotranspiração. Campinas: Fundag, 2013. 318p.

PRIESTLEY, C. H. B.; TAYLOR, R. J. On the assessment of surface heat flux and evaporation using large-scale parameters. Monthly Weather Review, v. 100, n. 2, p. 81-92, 1972. http:/ /dx.doi. org/10.1175/1520-0493(1972)100<0081:OTAOSH>2.3.CO;2.
PUTUHENA, W.; CORDERY, I. Estimation of interception capacity of the forest floor. Journal of Hydrology, v. 180, n. 1-4, p. 283-299, 1996. http://dx.doi.org/10.1016/0022-1694(95)02883-8.

REID, L. M.; LEWIS, J. Rates, timing, and mechanisms of rainfall interception loss in a coastal redwood forest. Journal of Hydrology, v. 375, n. 3-4, p. 459-470, 2009. http://dx.doi.org/10.1016/j. jhydrol.2009.06.048.

REYS, P.; CAMARGO, M. G. G.; GROMBONE-GUARATINI, M. T.; TEIXEIRA, A. P.; ASSIS, M. A.; MORELLATO, L. P. C. Estrutura e composição florística de um Cerrado sensu stricto e sua importância para propostas de restauração ecológica. Hoehnea, v. 40, n. 3, p. 449-464, 2013. http://dx.doi.org/10.1590/S223689062013000300005 .

ROSALEM, L. M. P. Invento para determinação da interceptação da chuva pela serrapilheira em ecossistema florestais. 2017. Dissertação (Mestrado Engenharia Hidráulica e Saneamento) - Escola de Engenharia de São Carlos, São Carlos, 2017.

ROSALEM, L. M. P.; CABRERA, M. C. M.; LEITE, C. M. C.; ANACHE, J. A. A.; WENDLAND, E. A produção de serrapilheira no Cerrado e sua aplicação temporal com o balanço hídrico climatológico. CONGRESSO BRASILEIRO DE ÁGUAS SUBTERRÂNEAS, 19., 2016, Campinas. Anais.... São Paulo: ABAS, 2016. http://dx.doi.org/10.14295/ras.v0i0.28733.

ROWE, L. K. Rainfall interception by an evergreen beech forest, Nelson, New Zealand. Journal of Hydrology (Amsterdam), v. 66, n. 1-4, p. 143-158, 1983. http://dx.doi.org/10.1016/0022-1694(83)90182-8.

SARI, V.; PAIVA, E. M. C. D.; PAIVA, J. B. D. Precipitação interna em Floresta Atlântica: comparação entre os sistemas de monitoramento fixo e móvel. Revista Brasileira de Recursos Hídricos, v. 20, n. 4, p. 849-861, 2015. http://dx.doi.org/10.21168/rbrh. v20n4.p849-861.

SARI, V.; PAIVA, E. M. C. D.; PAIVA, J. B. D. Interceptação da chuva em diferentes formações florestais na região sul do Brasil. Revista Brasileira de Recursos Hidricos, v. 21, n. 1, p. 65-79, 2016. http://dx.doi.org/10.21168/rbrh.v21n1.p65-79.

SATO, Y.; KUMAGAI, T.; KUME, A.; OTSUKI, K.; OGAWA, S. Experimental analysis of moisture dynamics of litter layers - the effects of rainfall conditions and leaf shapes. Hydrological Processes, v. 18, n. 16, p. 3007-3018, 2004. http://dx.doi.org/10.1002/hyp.5746.

SCHELLEKENS, J.; SCATENA, F. N.; BRUIJNZEEL, L. A.; WICKEL, A. J. Modelling rainfall interception by a lowland tropical rain forest in northeastern Puerto Rico. Journal of Hydrology (Amsterdam), v. 225, n. 3-4, p. 168-184, 1999. http://dx.doi. org/10.1016/S0022-1694(99)00157-2.

SEYFFARTH, J. A. S. Interceptação de chuva em cerrado sensu stricto sob diferentes regimes de queima. 1995. Dissertação (Mestrado em Ecologia) - Departamento de Ecologia da Universidade de Brasília, Universidade de Brasília, Brasília, 1995. 
STEIDLE NETO, A. J.; RIBEIRO, A.; LOPES, D. C.; SACRAMENTO NETO, O. B.; SOUZA, W. G.; SANTANA, M. O. Simulation of rainfall interception of canopy and litter in eucalyptus plantation in tropical climate. Forest Science, v. 58, n. 1, p. 54-60, 2012. http:// dx.doi.org/10.5849/forsci.09-120.

THOMAZ, E. L.; ANTONELI, V. Rain interception in a secondary fragment of araucaria forest with faxinal, Guarapuava-PR. Cerne, v. 21, n. 3, p. 363-369, 2015. http://dx.doi.org/10.1590/010477 60201521031736.

TONELLO, K. C.; GASPAROTO, E. A. G.; SHINZATO, E. T.; VALENTE, R. O. A.; DIAS, H. C. T. Precipitação efetiva em diferentes formações florestais na Floresta Nacional de Ipanema. Revista Árvore, v. 38, n. 2, p. 383-390, 2014. http:// dx.doi.org/10.1590/S0100-67622014000200020.
TSIKO, C. T.; MAKURIRA, H.; GERRITS, A. M. J.; SAVENIJE, H. H. G. Measuring forest floor and canopy interception in a savannah ecosystem. Physics and Chemistry of the Earth, v. 47-48, p. 122-127, 2012. http://dx.doi.org/10.1016/j.pce.2011.06.009.

\section{Authors contributions}

Livia Malacarne Pinheiro Rosalem: Conception and design of experiments, experiments performing, data analysis and paper writing.

Jamil Alexandre Ayach Anache: Data analysis and paper writing.

Edson Wendland: Conception and design of experiments and paper writing. 